\title{
Historical accounts of the transformation of a prairie town
}

Todd D. Fagin

Oklahoma Biological Survey and

University of Oklahoma

Department of Geography
Melissa Scott Brown

University of Oklahoma

Department of Geography

Center for Spatial Analysis

Prior to European settlement, the area that would later become Norman, Oklahoma was dominated by prairie vegetation. Woody vegetation was limited to riparian zones and isolated groves presumably protected from the effects of fire. The contemporary landscape of Norman, stands in stark contrast to this "treeless" prairie, and is now characterized by a so-called urban forest. In this paper, we analyze a number of archival sources, ranging from early expedition and traveler accounts to postsettlement photography in order to qualitatively assess the nature of the landscape in and around the present-day city of Norman prior to and immediately following European settlement. We also utilize repeat photography to document the floristic and vegetation changes that have occurred. We found that the pre-European settlement landscape was characterized by rolling prairies heavily influenced by the grazing of black-tailed prairie dogs (Cynomys ludovicianus), bison (Bison bison), and pronghorn antelope (Antilocapra americana). Forbs were limited and herbaceous vegetation was dominated primarily by closely grazed grasses. Woody vegetation was limited primarily to watercourses and ravines, though numerous accounts cite thickets of oaks (Quercus spp.) occurring in the adjacent cross timbers. Today, the vegetation of Norman is characterized by the dominance of woody vegetation. Within Norman's historical residential areas, commonly occurring species include hackberry (Celtis occidentalis), Shumard's oak (Q. shumardii), silver maple (Acer saccharinum), and sycamore (Platanus occidentalis).

\section{INTRODUCTION}

A contemporary aerial view of Norman, Oklahoma, (Table; Figure 1) shows a landscape replete with trees and sloping gently from northwest to southeast. Below the seemingly dense canopy lies Norman's residential and commercial areas, all but obscured by the towering sycamore (Platanus occidentalis L.), hackberry (Celtis occidentalis L.), pecan (Carya illinoensis (Wangenh.) K. Koch, elm (Ulmus spp.), and numerous other species, native and nonnative alike. Unknown to many, this urban forest is an anomaly, standing in stark contrast to what once was the standard throughout much of the southern Great Plains. While the North American prairies that covered more than 350 million ha in the Central Lowlands prior to European settlement (Clements 1920; Gleason 1922; 
Axelrod 1985) have succumbed largely to the plow and urban sprawl, Norman's vegetative fate resided in earlier settlers' conception of an ideal environment (Gumprecht 2001). Aggressive tree planting fueled by these notions and widespread fire suppression followed a half-century of belligerent extirpation of native flora and fauna. The result has been an environment quite unlike the surrounding matrix of monoculture agriculture, remnant grasslands, and post oak-black jack oak (Quercus stellata Wang.-Q. marilandica Muench.) woodlands.

In this paper, we use a number of archival sources, ranging from early traveler accounts to historical photographs to qualitatively assess the pre-European settlement vegetation of the area that would later become Norman. We also utilize repeat photography, the practice of finding the original location of a historic photograph of a landscape, determining and re-occupying the original camera position, and taking a repeat photograph of the same scene (Bahre 1991; Veblen and Lorenz 1991), as a means to document the rapid transformation of one of the last vestiges of the North American prairies. The results presented here are preliminary, and will later be incorporated into a larger study that seeks to determine the biogeographic and ecological implications of afforestation of former prairie environments.

\section{MATERIALS AND METHODS}

Study Area

The city of Norman is the county seat of Cleveland County and located in central Oklahoma approximately 28 kilometers south of the state capital in Oklahoma City. Norman currently covers an area of 49,083 ha, of which approximately 3,519 ha are urban. The area primarily under consideration for this study, though, encompasses the original Norman townsite, as well as the adjacent areas that were developed within forty years of the initial European settlement (core area; Figure 2). Norman has the third largest population in the state (USCB 2000). European settlement began in 1889 (Womack 1976; Gumprecht 2001) and has increased at a steady rate since. The first census enumeration occurred in June 1890 and placed Norman's population at 817 (Womack 1976). The most recent census enumeration places the population of Norman at 95,694 (USCB 2000).

The topography is generally flat to rolling and slopes from an elevation of 349 $\mathrm{m}$ to $313 \mathrm{~m}$. Mean annual precipitation is $148 \mathrm{~mm}$ (37.6 in.) with the precipitation maxima during the months of March through June. Mean annual temperature is $15.6^{\circ} \mathrm{C}\left(60.1^{\circ} \mathrm{F}\right)$. Summers are typically humid and hot, with an average temperature of $26.7^{\circ} \mathrm{C}\left(80^{\circ} \mathrm{F}\right)$, while the average winter temperature is $4^{\circ} \mathrm{C}\left(39.2^{\circ} \mathrm{F}\right)$ (Oklahoma Climatological Survey 2002).

The potential natural vegetation (PNV) of Norman is a matrix of tallgrass prairie, post oak-black jack oak forests, and bottomland forest (Duck and Fletcher 1945; Figure 3), though the PNV of the core area is solely tallgrass prairie. According to this schema, the pre-settlement PNV of the core area would have been dominated by big bluestem (Andropogon gerardii Vitman), little bluestem (Schizachyrium scoparium (Nash) Bickn.), Indian grass (Sorghastrum nutans (L.) Nash), and switch grass (Panicum virgatum L.), and may have also consisted of buffalo grass (Buchlö̈ dactyloides (Nutt.) Engelm.), blue grama (Bouteloua gracilis (Willd. ex Kunth) Lag. ex Griffiths) and side oats grama (Bouteloua curtipendula (Michx.) Torr.) (Duck and Fletcher 1943).

\section{Historical Documentation}

In order to qualitatively assess the nature of the Norman landscape prior to and shortly after European settlement, we 
analyzed a number of historical documents, ranging from expedition and travel accounts to descriptions of the landscape by earlier settlers. Of particular note are the accounts of military expeditions commissioned by the U.S. government to survey Indian lands and the western frontier (Womack 1976). Moreover, we analyzed midnineteenth century travel accounts by the likes of Washington Irving (1956) and Josiah Gregg (1954) in order to glean useful information about the preEuropean settlement landscape in and around the future Norman townsite. Finally, we analyzed early settler accounts, primarily in the form of newspaper articles appearing in the territorial newspaper, The Norman Transcript (Womack 1976).

\section{Photographic Documentation}

The Western History Collections at the University of Oklahoma houses a rich collection of photographs of the Norman landscape immediately following European settlement through its historical development. We acquired a set of those photographs that were apropos to our study. We then used basic photographic interpretation to analyze the vegetation and flora (when applicable) of the core area of Norman at intervals corresponding to the availability of photographs. We also returned to those areas that could be precisely relocated and re-photographed the landscape as a means to document vegetation changes.

\footnotetext{
RESULTS AND DISCUSSION Military Expeditions and Travel Accounts In the period between 1740 and 1889 , there were at least ten known reconnoissances of the area that would become Norman (Table; Figure 4). The earliest of these was carried out by the French explorers Pierre and Paul Mallet,
}

who descended on the Canadian River upon their return trip from Santa Fe, New Mexico to the French settlements in Illinois (Hoig 1998). The original journal of the Mallet expedition has been lost, and all that remains is a summary of the journal sent to Paris by Governor Bienville of the French colony of Louisiana (Blakeslee 1995). Based on a recreation of the trail followed by the expedition (Blakeslee 1995), Mallet would have passed south of the present-day location of Norman on or around the $13^{\text {th }}$ or $14^{\text {th }}$ of June, 1740. However, the journal summary does not contain an adequate description of the landscape encountered in route to the French territories.

The first landscape descriptions of present-day Norman came some eighty years later when Major Stephen H. Long's party traversed the area in 1820 (Womack 1976; Goodman and Lawson 1995). In late August 1820, Long's scientific expedition to find the headwaters of the Platte, Arkansas, and Red Rivers crossed the $98^{\text {th }}$ meridian heading east towards the future site of Norman. Long's map of his expedition placed the future townsite of Norman on the periphery of the so-called "Great Desert" and south of the region he described as "Extensive Plains with broad swells" (James 1823). Long did not otherwise describe the area in which present-day Norman occurs.

Among the scientific staff of the Long expedition was Edwin James whose careful chronicling and extensive plant collection provides one of the clearest pictures of the pre-settlement flora and fauna of the Southern Great Plains (Goodman and Lawson 1995). Though there is uncertainty as to when exactly the Long expedition crossed the area to become Norman (Womack 1976; Goodman and Lawson 1995), James' (1823) accounts of the vicinity are nonetheless quite useful in establishing an idea of the pre-settlement landscape. 
James and the Long expedition arrived in or around present-day Norman on August $28^{\text {th }}$ and $29^{\text {th }}$ (Goodman and Lawson (1995). A journal entry from that time describes "extensive forests (that) appeared in the distant horizon, and prairies in every direction intersected by creeks and ravines, distinguished by lines of forest." Long's entourage traveled "a few miles across the open plains," which were covered by a "large and uncommonly beautiful village of the prairie marmots (sic), covering an area of about a mile square, having a smooth surface, and sloping almost imperceptibly to the east" (James 1823). The grasses here were "fine, thick, and close fed" (James 1823), as one would expect in a prairie dog (Cynomys ludovicianus Ord) town (Hoogland 1995). James (1823, Pp. 148) also reported that the plains of the area were "covered with a herd of some thousands of bisons (sic); on the left a number of wild horses, and before us 20 or 30 antelopes, and about half as many deer."

Of particular note was James' (1823) tendency to identify number of plants he encountered to species level. As a trained botanist, James (1823) reported encountering a number of forbs, including cardinal flower (Lobelia cardinalis L.), copperleaf (Acalypha spp.), sunflowers (Helianthus spp.), ragweed (Ambrosia spp.), and "other heavy weeds" during the Long expedition's reconnaissance of the Norman area, and amongst the woody plants reported in the area were honey locust (Gleditsia triacanthos L.), eastern cottonwood (Populus deltoides Bartr. ex Marsh.), sycamore, and "thickets of" oak (Quercus spp.) and elm (Ulmus spp.). However, James' (1823) descriptions of the habitats in which each of the species encountered and collected occurred were often limited.

Henry L. Ellsworth, the newly appointed commissioner to treat with western Indians, led the next known expedition to reconnoiter the area in the vicinity of present-day Norman (Womack 1976). The famous writer Washington Irving and his entourage (Ellsworth 1937; Latrobe 1955; de Pourtalès 1968) were invited to travel with the Ellsworth expedition, and passed through the future townsite of Norman on August 29, 1832. Irving's (1956) account of the "great Prairie" is perhaps the most vivid of Norman's pre-settlement landscape. After emerging from the "dreary belt of the Cross Timbers" (post oak-black jack oak forest), Irving wrote of the "infinite delight" he felt as he "beheld the 'great Prairie' stretching to the right and left before us." According to Irving, the "landscape was vast and beautiful" consisting of "boundless and fertile wastes." The only mention of woody vegetation upon the prairie was the "strips of green forest" that bordered the Canadian River and its tributaries.

The Irving party's venture into present day Norman was marked by a buffalo hunt. Like James' (1823) account of the area, Irving (1956, Pp. 139) commented, "the prairies of the hunting ground are not so much entangled with flowering plants and long herbage as the lower prairies and are principally covered with short buffalo grass." Such descriptions are echoed in accounts of the area by Hildreth (1836), Boone (1929); Hurt (1998), and Gregg (1954). Hildreth (1836) described "an immense herd of buffalo", while Boone described a "beautiful plain" replete with "countless numbers of buffalo" (Hurt 1998). Gregg (1954, p. 235) echoed these sentiments, recounting the "little herds of buffalo" amongst a "beautifully variegated" landscape "with stripes and fringes of timber." 


\section{Captain Nathan Boone returned} to the area in July 1843 and commented that the "rolling prairies [were] intersected by numerous wooded creeks rendering the scenery very pleasing to the eye. The "flat prairie country" was "very much parched by the summer heat" and "vegetation was very scant." He noted that the "buffalo grass" was "eaten down very close by the buffalo." (Boone 1929). Likewise, Captain R.B. Marcy (Foreman 1939), reflecting on the area on the eastern edge of the cross timbers, wrote, "the country... has been entirely prairie, with the exception of a few scattering trees." Sherburne (1988), the diarist for the Whipple expedition, noted that the area presumably between present day Lexington and Norman was "still a vast prairie with a few scattering trees." Among the trees encountered was a tree "with a peculiar appearance ...[t]he bark had peeled off leaving the wood perfectly white, \& it looked precisely as though it had been whitewashed." Sherburne (1988, p. 65) identified the tree as a "Cotton wood", though it most likely was a sycamore.

These accounts offer perhaps the best insight to Norman's pre-settlement vegetation structure and composition. The current city of Norman has a PNV dominated by tallgrass prairies (Duck and Fletcher 1943). However, the presence of numerous grazers, such as the American bison (Bison bison L.), North American elk (Cervus canadensis Ord), pronghorn antelope (Antilocapra americana Ord), and black-tailed prairie dog, all of which were recorded to have occurred in the area prior to settlement (James 1823; Gregg 1954; Irving 1956) resulted in grasses of a diminutive structure. Within prairie dog colonies, for instance, vegetation is conspicuously lower than surrounding vegetation, and the plant community composition thereof is also markedly different from surrounding plant communities (Hoogland 1995). Similarly, generalist grazers, such as bison, have been shown to have a tremendous effect on the physiognomy of grassland communities (Milchunas et al. 1988).

The half century leading to settlement of present-day Norman, though, was characterized by a rapid and belligerent campaign of faunal extirpation throughout the southern Great Plains (Flores 2001). The effects of this faunal extirpation on the vegetation of present day Norman at the time of settlement are unknown. However, earlier settler accounts, documented primarily in the city's first territorial paper, The Norman Transcript, offer some insight. From the first year of publication alone, we found thirteen accounts of the wildlife in the area, as well as numerous accounts describing the landscape of the area. For instance, a July 13, 1889 press notice described "prairies...covered with beautifully blossoming" and varied wildflowers. Moreover, much of the game cited in the area, such as the lesser prairie chicken (Tympanuchus pallidicinctus Ridgway), are often associated with short and mixed grass prairies interspersed with some tall grasses (Woodward et al. 2001).

Photographic Documentation: 1889-Present In the months following the opening of the unassigned lands of Oklahoma to European settlers, an aggressive campaign of afforestation began in the Norman townsite (Gumprecht 2001). This often belligerent campaign has continued more or less unabated into the present and has led to the designation of Norman as a 'Tree City U.S.A.' (Blakey 2002), a title bestowed by the National Arbor Day Foundation upon cities that take an active role in urban forestry. This afforestation, coupled with fire suppression, has resulted in a contemporary landscape that differs 
markedly from the landscape described by James (1823), Irving (1956), and others.

Much of the transformation that has occurred over the past 114 years has been photographically documented. Currently, many historical photographs related to Norman's growth are available in the Western History Collections at the University of Oklahoma. We acquired sixteen historical photographs from the Western History Collections that were apropos to our study. Of these, the earliest photographs were dated to June 1889 , two months after the unassigned lands (which included Norman) were opened to European settlement. The most recent photographs from these collections date to 1939 . Of these sixteen photographs, we were able to accurately relocate thirteen vantage points in order to re-photograph the scenes.

Among the earliest photographs taken of the Norman townsite is a view looking east on Main St. from the railroad tracks (Figure 5a). The landscape is austere, punctuated by two rows of makeshift wooden buildings. No woody vegetation is present in the photograph. Rather closely shorn grasses dominate the landscape, while a lone wavyleaf thistle (Cirsium undulatum Nutt.) stands in the foreground of the photograph. The area was re-photographed in 1939 (Figure $5 b)$. Though more permanent structures have replaced the temporary wooden buildings and asphalt now dominates the erstwhile prairie, the only woody vegetation visible in the photograph dots the distant residential area (far eastern end of Main St.). A contemporary view of Main St. (Figure 5c) stands in contrast to the two historic photographs. While many of the same structures present in the 1939 photograph remain, the sidewalks are lined with several species of woody plants, most notably live oak (Quercus virginiana Mill.), eastern redbud (Cercis canadensis L.) and Bradford pear (Pyrus calleryana Dcne.).

Another photograph taken in newly established Norman townsite depicts the view south from Main St. along the railroad tracks (Figure 6a). Much like the photograph looking east on Main St. from the railroad tracks, the landscape in this photograph is austere, marked by lowgrowing grasses. A contemporary view looking south from Main St. along the railroad tracks (Figure 6b) indicates that the area immediately adjacent to the railroad tracks remains largely depauperate of woody vegetation. However, the parallel road, marking the beginning of one of Norman's historical neighborhoods, as well as parkland, are lined with numerous species of woody plants, including species of pine (Pinus spp.), bald cypress (Taxodium distichum (L.) Rich.), Chinese pistachio (Pistacia chinensis Bunge), American elm (Ulmus americana L.), lacebark elm ( $U$. parvifolia Jacq.), pecan, hackberry, mimosa (Albizia julibrissin Durazzini), eastern redcedar (Juniperus virginiana L.), and cottonwood (Populus deltoids Marsh.).

The rapid afforestation of the Norman townsite is perhaps best illustrated by two early views of David Ross Boyd's, the first president of the University of Oklahoma, house (Figure 7a). The first photograph, taken in 1895 , shows a row of American elm saplings. Within a year, the saplings around the Boyd House had experienced vigorous growth. Today, a row of lacebark elm flank the eastern side of the Boyd House, while numerous other species, native and nonnative alike, such as tulip poplar (Liriodendron tulipifera L.), paper birch (Betula papyrifera Marsh.), swamp white oak (Quercus bicolor Wild.), and eastern redbud (Cercis canadensis L.) (Figure 7b) decorate the landscape. 
By the 1930s, much of Norman's residential areas had been adorned with trees, as is evident in an undated photograph depicting rows of evenly aged elms and maples lining a city street (Figure 8a). A contemporary view of a similar residential street (Figure $8 \mathrm{~b}$ ) is indicative of many streets throughout Norman, especially within the core settlement area after 40 years of initial settlement. American elms, sycamores, hackberries, and cottonwoods tower above residential homes and smaller woody species, such as eastern redbud and various maples (Acer spp.).

\section{Contemporary Vegetation}

The contemporary Norman

landscape leaves few traces of the erstwhile prairie that so awed Irving (1956) and others. Indeed, in 1999, the Norman Park Foundation received a grant to inventory woody vegetation located on public property, the purpose thereof to create a database for the management of a portion of the urban forest resource (Hennessey 2000). During May-June 2000, Hennessey (2000) inventoried and mapped every tree growing on City of Norman right-of ways within an approximate $1.3 \mathrm{~km}^{2}(0.5$ $\mathrm{mi}^{2}$ ) area in the core area. Trees located on private property, which represents the bulk of the trees in this area, were not inventoried.

A total of 1,141 trees

representing 48 species were documented by Hennessey (2000). Of the 48 species, 15 species comprising $590(52 \%)$ individuals are within their historic range, 13 species comprising $383(33 \%)$ individuals are native to Oklahoma but outside their historic range, and 20 species comprising 168 $(15 \%)$ individuals are not native to Oklahoma. The most frequently occuring species include hackberry,
Shumard's oak (Q. shumardii Buckl.), silver maple (Acer saccharinum L.), and sycamore. Data are provided by Hennessey (2000).

\section{CONCLUSIONS}

During the past several decades, ecologists, biogeographers, and others have begun to pay increasing attention to anthropogenic environments, in general, and urban environments specifically (Gilbert 1989; Pyšek 1993 ; Kent et al. 1999). As the last vestiges of the North American prairies are swept away by wheat and concrete, it becomes increasingly imperative to document the specific nature of the change, as well as the possible biological and ecological consequences. Within the span of a little more than a century, the entire vegetation and flora of the area comprising the city of Norman has been radically transformed. Documenting these changes has been relatively easy. Understanding this transformation in terms of the broader ecology of the region is the real challenge.

\section{ACKNOWLEDGMENTS}

The authors recognize the invaluable contributions of the following individuals: Dr. Bruce Hoagland, Oklahoma Biological Survey and Department of Geography at the University of Oklahoma; John Lovett and Jaymie Lang, University of Oklahoma Western History Collections; Dr. Thomas Hennessey, Department of Forestry at Oklahoma State University; Joyce Green, City of Norman; Dr. Blake Gumprecht, Department of Geography at the University of New Hampshire; Dr. Bret Wallach, Dr. Richard Nostrand, Helen Robertson, Catherine Blaha, and Kaye Carter, Department of Geography at the University of Oklahoma; Dr. Donald J. Blakeslee, Department of Anthropology at Wichita State University; Amy Buthod, Oklahoma 
Biological Survey; and Sarah Ritter, formerly of University of Oklahoma Press.

\section{REFERENCES}

Abert, J.W. 1999. Expedition to the Southwest: an 1845 reconnaissance of Colorado, New Mexico, Texas, and Oklahoma. Lincoln, NE: University of Nebraska Press.

Axelrod, D.I. 1985. Rise of the grassland biome. Bot. Rev. 51:163-201.

Bahre, C.J. 1991. A legacy of change: Historic Human Impact on vegetation in the Arizona borderlands. Tucson, AZ: The University of Arizona Press.

Blakey, Tom. April 8, 2002. Norman could become a "Tree City U.S.A." Norman Transcript.

Blakeslee, D.J. 1995. Along ancient trails: the Mallet Expedition of 1739. Niwot, CO: University of Colorado Press.

Boone, N. 1929. Captain Nathan Boone's journal. W. Julian Fessler (Ed.) Chron. of Ok. 7: 58-105.

Clements, F.E. 1920. Plant Indicators: the relation of plant communities to process and practice. Washington, D.C.: Carnegie Institution of Washington.

de Pourtalès, C. 1968. On the western tour with Washington Irving: the journal and letters of Count de Pourtalès. G.F. Spaulding (Ed.) Norman: OK: University of Oklahoma Press.

Duck, L.G. and J.B. Fletcher. 1943. The game types of Oklahoma: a report to the Oklahoma Game and Fish Commission. Oklahoma City, OK: Oklahoma Game and Fish Commission, Division of Wildlife Restoration and Research.
Duck, L.G. and J.B. Fletcher. 1945. Survey of the game and furbearing animals of Oklahoma. Oklahoma City, OK: Oklahoma Game and Fish Commission, Division of Wildlife Restoration and Research.

Ellsworth, H.L. 1937. Washington Irving on the prairie, or a narrative of a tour of the Southwest in the year 1832. S.T. Williams and B.D. Simison (eds.). New York, NY: American Book Company.

Flores, D. April 7, 2001. The elusively beautiful plains. [Op-ed. excerpted from address at the Sharp Symposium in History at Southern Methodist University]. Dallas, TX: SMU News and Information.

Foreman, G. 1939. Marcy \& the gold seekers: The journal of Captain R.B. Marcy, with an account of the gold rush over the southern route. Norman, OK: University of Oklahoma Press.

Gilbert, O.L. 1989. The ecology of urban habitats. London: Chapman and Hall.

Gleason, H.A. 1922. The vegetational history of the Middle West. Ann. Assoc. Amer. Geogr. 12:39-83.

Goodman, G.J. and C.A. Lawson. 1995. Retracing Major Stephen H. Long's 1820 expedition: the itinerary and botany. Norman, OK: University of Oklahoma Press.

Gregg, J. 1954. Commerce on the prairies. M.L. Moorhead (Ed.). Norman, OK: University of Oklahoma Press.

Gumprecht, B. 2001. Transforming the prairie: early tree planting in an Oklahoma town. Hist.Geogr. 29:116-134.

Hennessey, T. 2000. City of Norman, Oklahoma tree inventory and assessment. Prepared for the City of Norman and the Norman Park Foundation. 
Hildreth, J. 1836. Dragoon campaigns to the Rocky Mountains: being a history of the enlistment, organization, and first campaigns of the regiment of United States dragoons; together with the incidents of a soldier's life, and sketches of scenery and Indian character. New York: Wiley and Long.

Hoig, S. 1998. Beyond the Frontier: exploring the Indian country. Norman, OK: University of Oklahoma Press.

Hoogland, J.L. 1995. The Black-Tailed Prairie Dog: social life of a burrowing mammal. Chicago, IL: The University of Chicago Press.

Hurt, R.D. 1998. Nathan Boone and the American frontier. Columbia, MO: University of Missouri Press.

Irving, W. 1956. A Tour on the Prairies. J.F. McDermott (Ed.) Norman, OK: University of Oklahoma Press.

James, E. 1823. Account of an expedition from Pittsburgh to the Rocky Mountains performed in the years 1819 and 1820: by order of the Hon. J.C. Calhoun, Secretary of War, under the command of Maj. S.H. Long, of the U.S. Top. Engineers. H. C. Carey and I. Lea. Philadelphia.

Kent, M., R.A. Stevens, and L. Zhang. 1999. Urban plant ecology patterns and processes: a case study of the flora of the City of Plymouth, Devon, UK. Journ. Biogeogr. 26:1281-1298.

Latrobe, C.J. 1955. The rambler in Oklahoma: Latrobe's tour with Washington Irving. M.H. Wright and G.H. Shirk (eds.) Oklahoma City, OK: Harlow Publishing Corporation.

Milchunas, D.G., O.E. Sala, and W.A. Lauenroth. 1988. A generalized model of the effect of grazing by large herbivores on grassland community structure. Amer. Natur. 132(1):87-106.

Morris, J.W., C.R. Goins, and E.C. McReynolds. 1986. Historical atlas of Oklahoma. Third Edition. Norman, OK: University of Oklahoma Press.

Norman Transcript. [Date unknown due to damaged reel, presumably 13 July, 1889]. [press notice]. Territorial Newspaper of Norman, OK.

Oklahoma Climatological Survey. 2002. Climate of Oklahoma.http://www.ocs.ou.edu

Pyšek, P. (1993) Factors affecting the diversity of flora and vegetation in central European settlements. Vegetatio 106:89100.

Sherburne, J.P. 1988. Through Indian Country to California: John P. Sherburne's diary of the Whipple Expedition, 18531854. M.M. Gordon (Ed.) Stanford, CA: Stanford University Press.

United States Census Bureau (USCB). 2000. Census 2000. http://www.census.gov/

Veblen, T.T. and D.C. Lorenz. 1991. The Colorado Front Range: a century of ecological change. Salt Lake City, UT: University of Utah Press.

Womack, J. 1976. Norman: An early history, 1820-1900. Norman, OK: [Published by the author].

Woodward, A.J., S.D. Fuhlendorf, D.M. Leslie Jr., and J. Shackford. 2001. Influence of landscape composition and change on Lesser Prairie-chicken (Tympanuchus pallidicnctus) populations. Amer. Midland Nat. 145(2):261-274. 


\begin{tabular}{|c|c|c|c|c|}
\hline \multicolumn{5}{|l|}{ TABLE } \\
\hline Expedition & Year & Date & General Description of Area & Sources \\
\hline Mallet & 1740 & June 13-14 & Original notes lost; description unavailable. & $\begin{array}{l}\text { Morris et al. (1986); Blakeslee (1995); Hoig } \\
\text { (1998) }\end{array}$ \\
\hline Long & 1820 & $\begin{array}{l}\text { Aug 26, 27, } \\
\text { or 28-29 }\end{array}$ & $\begin{array}{l}\text { Prairies in every direction intersected by wooded } \\
\text { creeks and ravines. }\end{array}$ & $\begin{array}{l}\text { Womack (1976); Morris et al.(1986); } \\
\text { Goodman and Lawson (1995); Hoig (1998) }\end{array}$ \\
\hline Irving et al. & 1832 & Oct. 29 & Great prairie; boundless fertile wastes. & $\begin{array}{l}\text { Womack (1976); Morris et al. (1986); Hoig } \\
\text { (1998) }\end{array}$ \\
\hline Levenworth & 1834 & Aug. 1-2 & Deer and buffalo abundant upon the prairie. & $\begin{array}{l}\text { Hildreth (1836); Womack (1976); Morris et } \\
\text { al. (1986) }\end{array}$ \\
\hline Gregg & 1839 & $\begin{array}{l}\text { May 18; } \\
\text { Apr 3, 1940 }\end{array}$ & Beautiful plains with countless numbers of bison. & $\begin{array}{l}\text { Womack (1976); Morris et al. (1986); Hoig } \\
\text { (1998) }\end{array}$ \\
\hline Boone & 1843 & July 19-20 & $\begin{array}{l}\text { Rolling prairies interesected by numerous wooded } \\
\text { creeks. }\end{array}$ & Womack (1976); Morris et al. (1986) \\
\hline Abert & 1845 & Oct. 8 & $\begin{array}{l}\text { Lowlands covered w/tall grass. Oaks forests in } \\
\text { distance. }\end{array}$ & Hoig (1988); Abert (1999) \\
\hline Marcy & 1849 & May 9-10 & $\begin{array}{l}\text { Entirely prairie, with the exception of a few } \\
\text { scattering trees. }\end{array}$ & Marcy (1939); Hollan (1955); Hoig (1998) \\
\hline Whipple & 1853 & Aug. 22-23 & Vast prairie with a few scattering trees. & Sherburne (1988); Hoig (1998) \\
\hline Beale & 1858 & Nov. 27-28 & Exclusively prairie; gently rolling and firm. & Beale 1860; Hoig (1998) \\
\hline
\end{tabular}

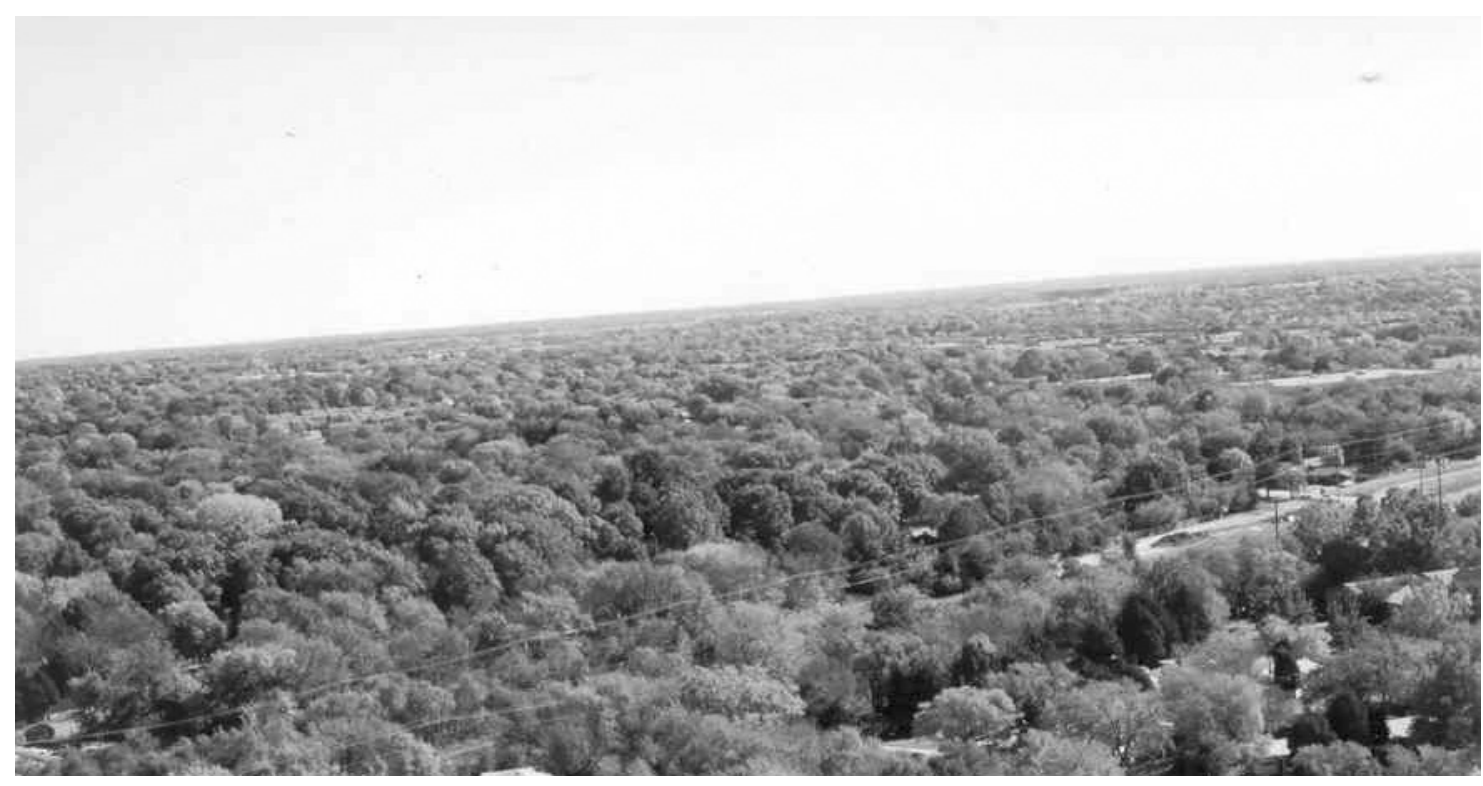

Figure 1. A contemporary aerial view of Norman, Oklahoma. Below this seemingly dense canopy of trees lies one of Norman's residential areas.

Fagin, T. D. and Brown, M. S. 


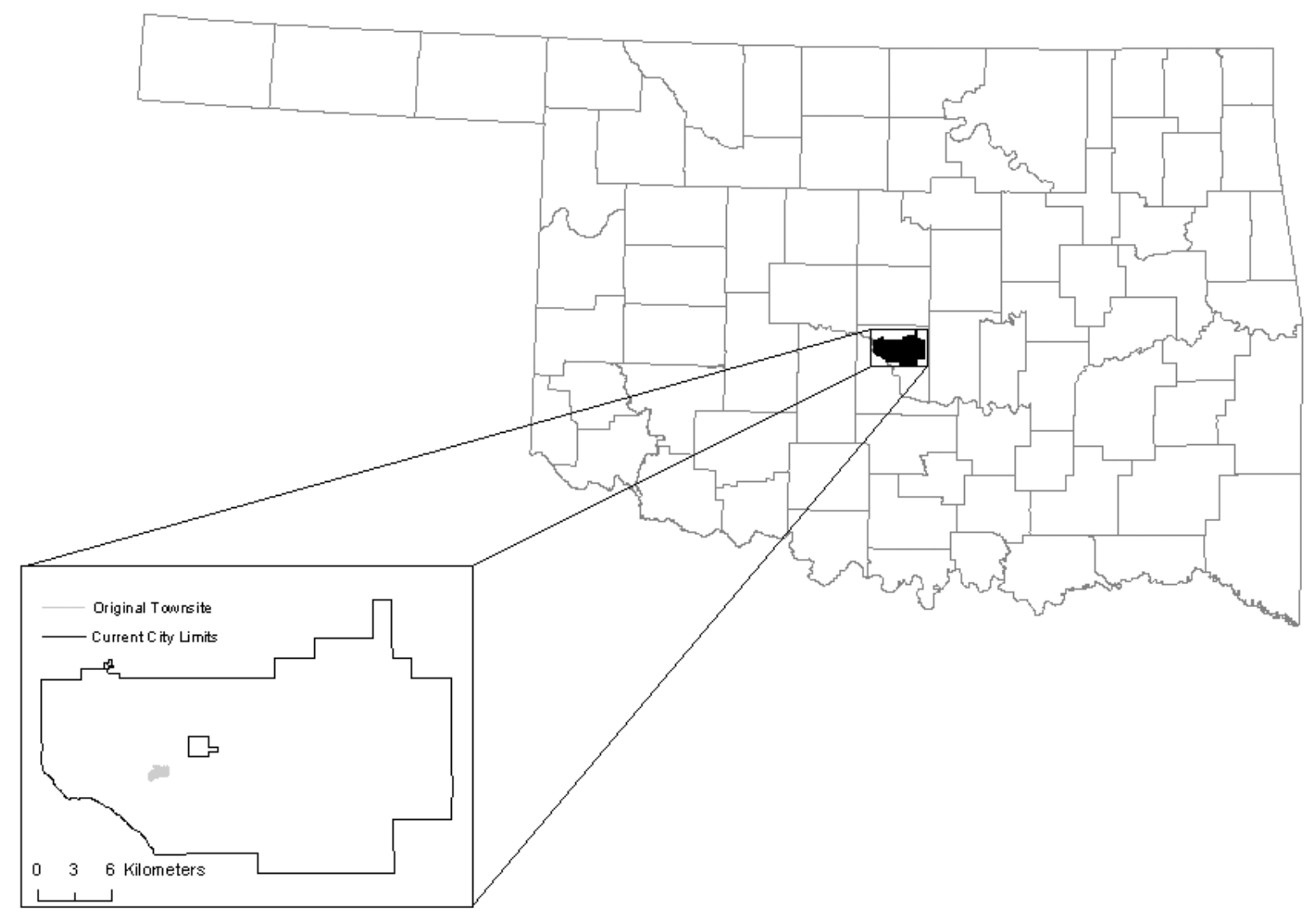

Figure 2. The study area; the present City of Norman boundary, in relationship to the state of Oklahoma and the original Norman townsite, settled in 1889. 


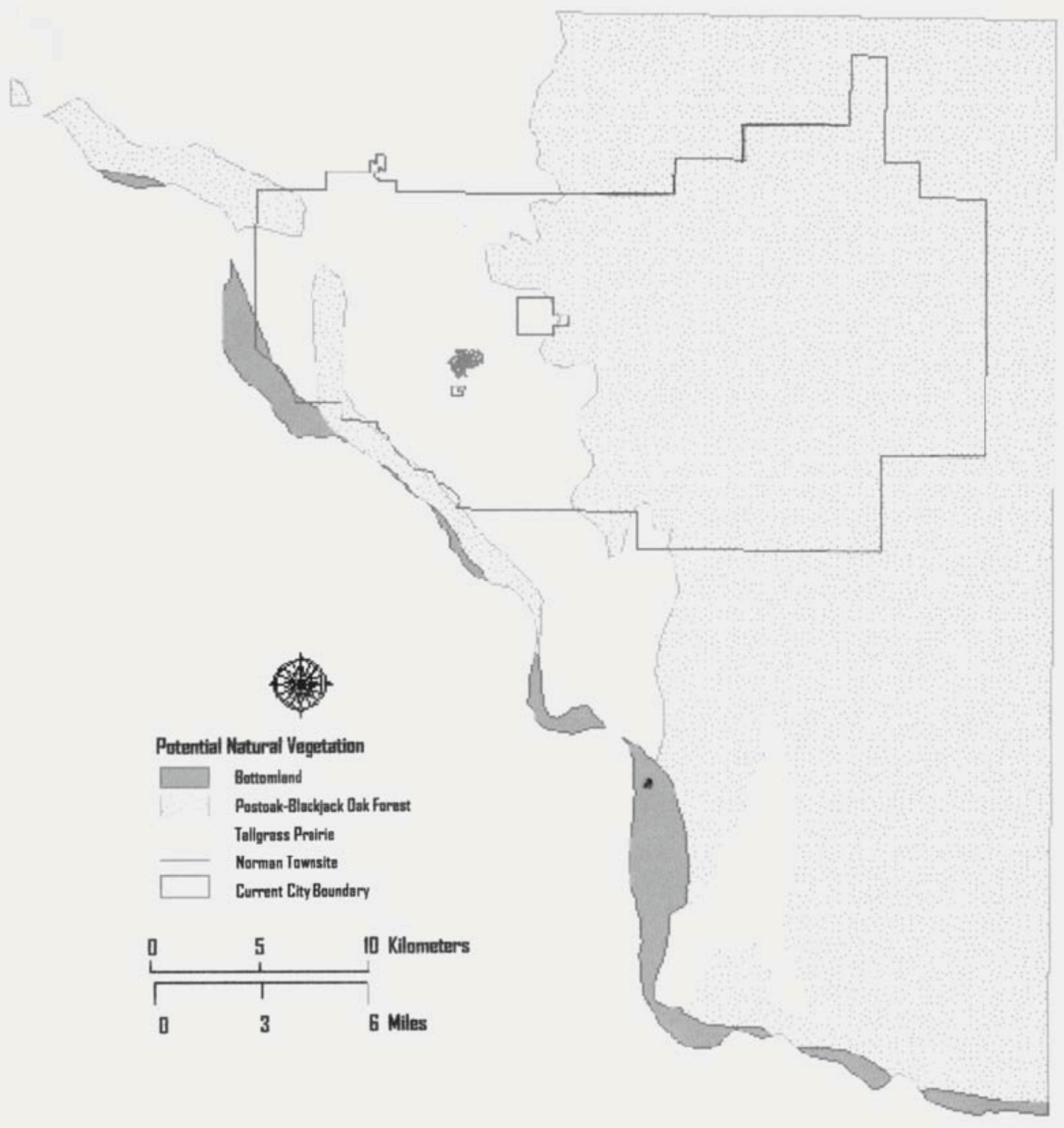

Figure 3. Potential Natural Vegetation (PNV) of Norman indicates that the area encompassing the townsite was once dominated by tallgrass prairie vegetation. After Duck and Fletcher (1943).

Fagin, T.D. and Brown, M.S. 


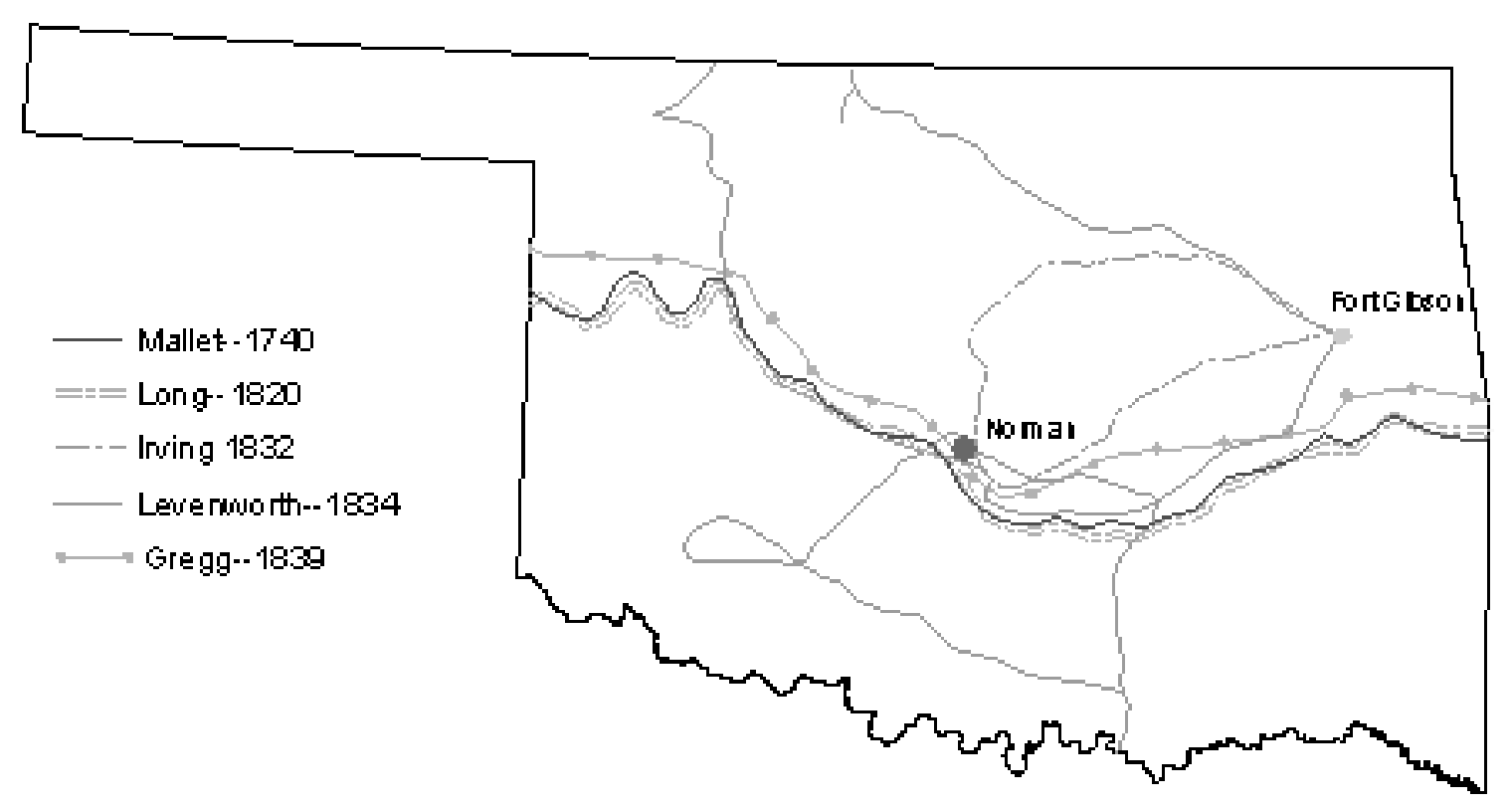

- Boone-- 1843

$\longrightarrow$ Abert-- 1845

- Marcy-- 1849

$=:$ : Whip ple-- 1853

$\longrightarrow$ Beale- 1858

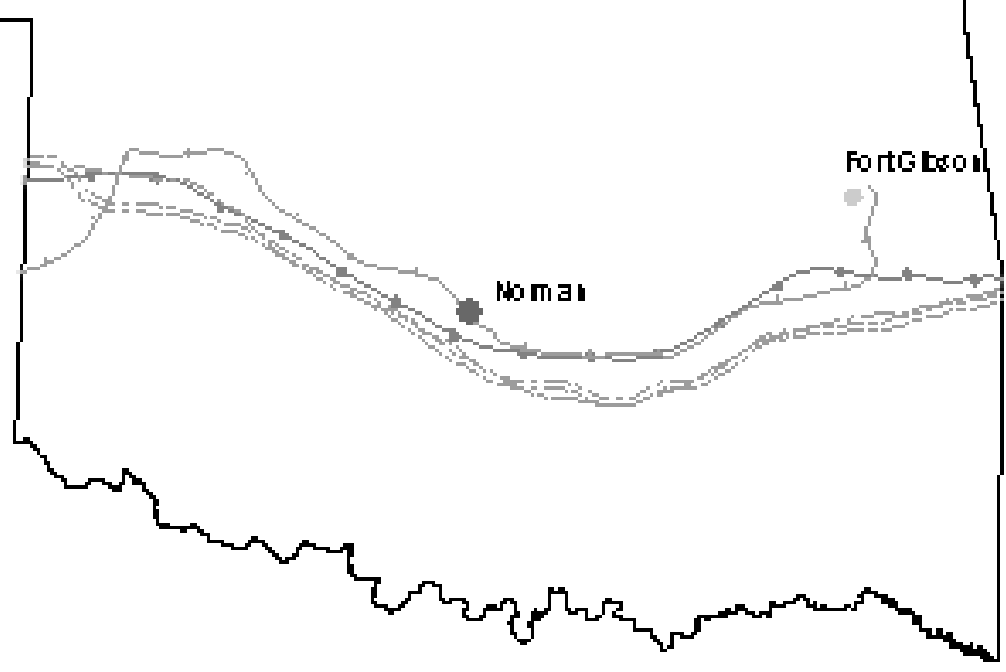

Figure 4. Routes of expeditions known to pass through present-day Norman and the vicinity, 1740-1858. After Morris et al. (1986) and Hoig (1998). 
A
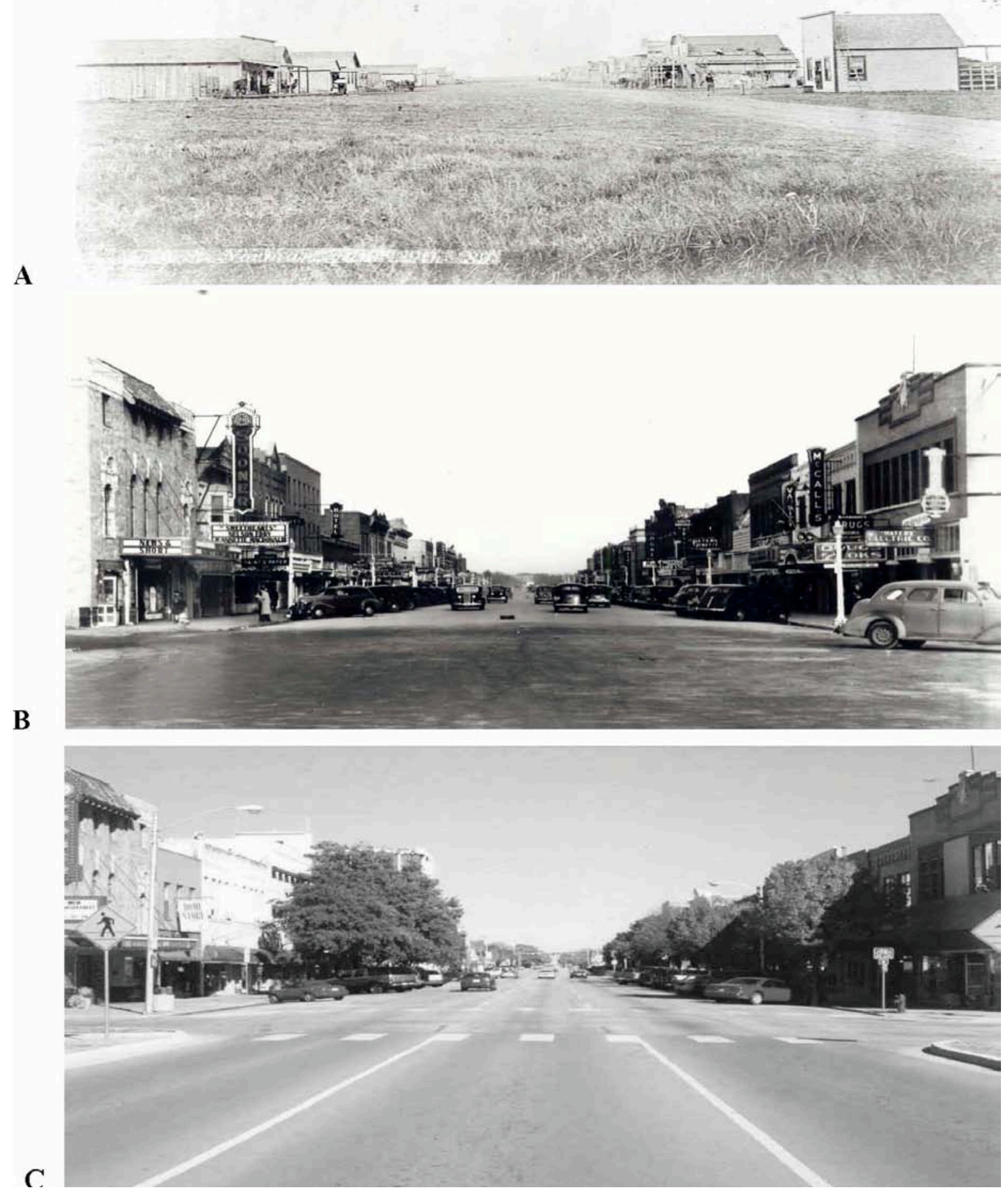

Figure 5. Main Street, looking east from the present site of the railroad tracks. A) June 1889; area dominated by short grasses, no woody vegetation visible. Lone thistle, Cirsium undulatum in foreground. B) 1939; Permanent structures replaced wooden buildings, asphalt replaced grasses. Woody vegetation only in residential area. C) Present; buildings flanked by woody plants, including Quercus virginiana, Cercis canadensis, and Pyrus calleryana. Historical photographs courtesy of the Western History Collections. Contemporary photograph by the authors.

Fagin, T.D. and Brown, M.S. 

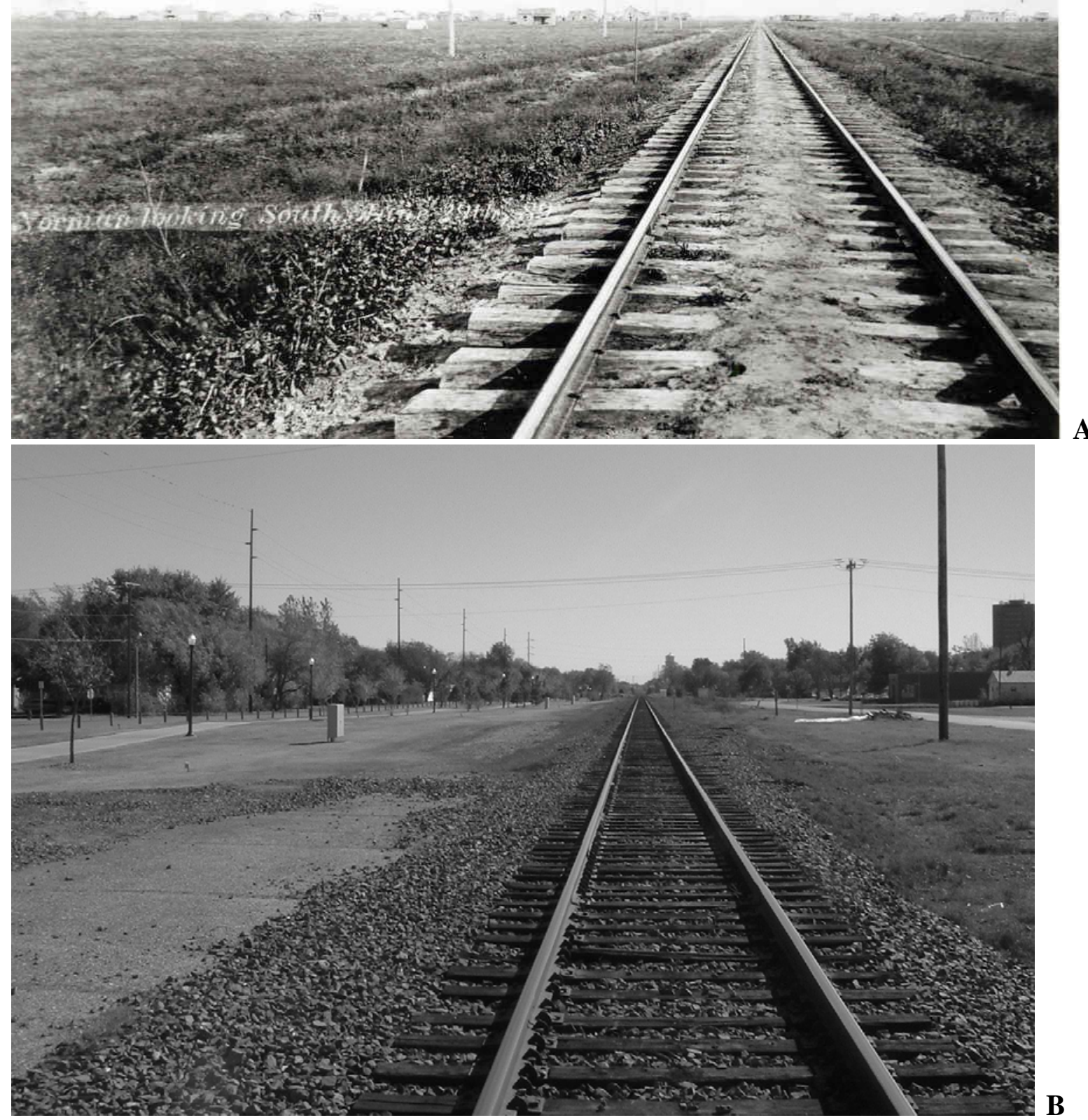

A

Figure 6. Views looking south on tracks from Main Street. A) June 1889; area dominated by short grasses. No woody vegetation visible. B) Present; railroad right-of-way flanked by numerous species of woody plants, including Taxodium distichum, Pistacia chinensis, Ulmus americana, U. parvifolia, Carya illinoensis, Celtis occidentalis, Albizia julibrissin, Juniperus virginiana, and Populus deltoids. Historical photograph courtesy of the Western History Collections. Contemporary photograph by the authors. 


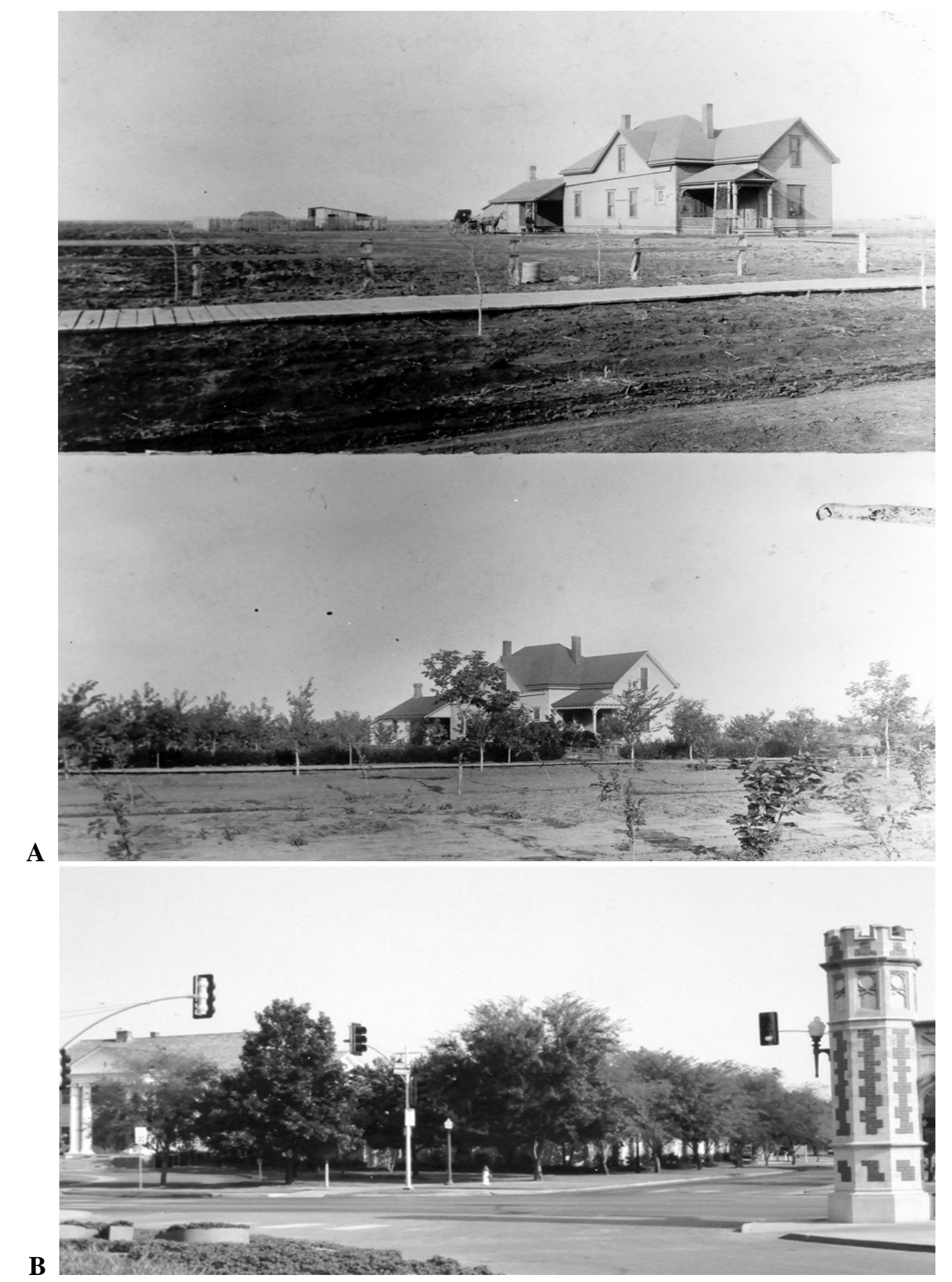

Figure 7. The Boyd House. A) 1895 and 1896; sequential photographs of the house of the first president of the University of Oklahoma, David Ross Boyd. In the first year the row of elm saplings experienced vigorous growth. B) Present; a row of Ulmus parvifolia flank the east side of Boyd House, Quercus bicolor stand in the foreground. Other species in the lawn include: Lirodendron tulipifera, Betula papyrifera, and Cercis canadensis. Historical photographys courtesy of the Western History Collections. Contemporary photograph by the authors.

Fagin, T. D. and Brown, M. S. 

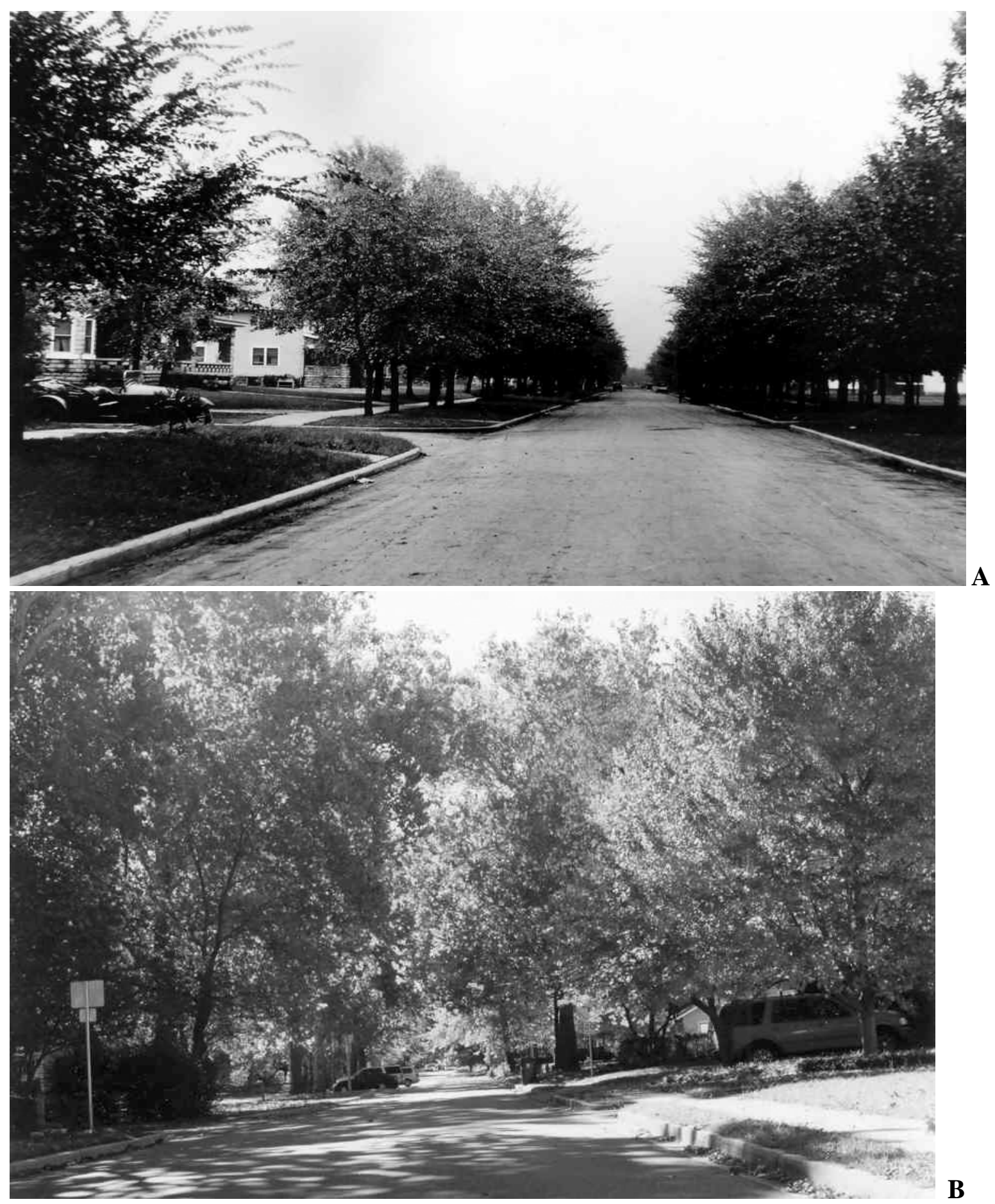

Figure 8. Two residential streets in Norman. A) Undated photograph depicting rows of evenly aged elms and maples lining a city street. B) Present view; a typical residential street in one of Norman's historical neighborhoods characterized by towering Platanus occidentalis, Ulmus Americana, and Populus deltoids. Understory vegetation includes species of Acer sp. and Cercis canadensis. Historical photograph courtesy of the Western History Collections. Contemporary photograph by the authors. 